CENDEKIA, Vol. 11, No. 2, Oktober 2017

p ISSN: 1978 2098; e ISSN: 2407 8557

Http://cendekia.pusatbahasa.or.id; Email: cendekiaoslo@gmail.com

Center of Language and Culture Studies, Surakarta, Indonesia

Sulistyaningrum, Indra. 2017. Mengulas Novel Remaja Menggunakan Model

Pembelajaran Think Pair Share pada Siswa SMPN 2 Malang.

Cendekia, (2017), 11(2): 159 170.

\title{
MENGULAS NOVEL REMAJA MENGGUNAKAN MODEL PEMBELAJARAN THINK PAIR SHARE PADA SISWA SMPN 2 MALANG
}

\author{
Indra Sulistyaningrum \\ SMP Negeri 2 Malang \\ Jalan Prof. Muhammad Yamin 60 Malang \\ indraintan03@gmail.com
}

\begin{abstract}
This study aims to improve the accomplishment to review teenager novel using the learning model of Think Pair Share. This study used classroom action research design with two cycles. The research subject was the eighth graders of SMP Negeri 2 Malang in the academic year 2013/2014 consisting of 32 students. This classrom action research applied four step cycle: planning, acting, observing and reflection. Data were collected using observation and interview and the data were analyzed using descriptive statistics. The results of the study showed that: attainment in the cycle I of this study was: average score 74.73 and the mastery learning $72 \%$. In the second cycle, the results were the average score as 84.53 and the mastery learning $98 \%$. The results of questionnaire evidently showed that the students were happy to learn using Think Pair Share and they enjoyed following the learning processes.
\end{abstract}

Keywords: review young adult novels, think pair share, learning outcomes

Belajar bahasa berarti belajar berkomunikasi. Artinya, terdapat keterkaitan dan pengaruh antara pembicara dan pendengar sehingga tujuan komunikasi tercapai dan tidak terjadi kesalahpahaman. Komunikasi melibatkan keterampilan berbahasa yang perlu dikuasai baik keterampilan menyimak, berbicara, membaca, maupun menulis. Keempat keterampilan tersebut tidak dapat dipisahkan karena saling memengaruhi. Menurut Atmazaki (2013:15) tujuan pembelajaran bahasa adalah membimbing perkembangan bahasa siswa secara berkelanjutan melalui proses mendengarkan, berbicara, membaca, dan menulis.

Keterampilan berbicara menuntut kemampuan pembicara untuk mengelola kalimat lisan secara baik dan benar. Tujuannya agar pendengar memahami isi pembicaraa. Mengulas novel remaja merupakan salah satu kompetensi dasar (KD) yang terdapat dalam pembelajaran bahasa Indonesia kelas VIII. Kompetensi ini terdapat pada KD berbicara sastra. Pembelajaran novel mewajibkan keterlibatan siswa baik dari segi fisik maupun mental. Kesungguhan dan kesiapan siswa dalam mengulas novel belum cukup optimal jika tidak ada keterlibatan siswa dari faktor kognitif, emosi, dan lingkungan sosial budaya siswa terhadap novel yang dibacanya. 
CENDEKIA, Vol. 11, No. 2, Oktober 2017

p ISSN: 1978 2098; e ISSN: 2407 8557

Http://cendekia.pusatbahasa.or.id; Email: cendekiaoslo@gmail.com

Center of Language and Culture Studies, Surakarta, Indonesia

Sulistyaningrum, Indra. 2017. Mengulas Novel Remaja Menggunakan Model

Pembelajaran Think Pair Share pada Siswa SMPN 2 Malang.

Cendekia, (2017), 11(2): 159 170.

Mengulas novel remaja berarti siswa harus memahami novel secara keseluruhan. Hal ini dikarenakan novel berisi kisah kehidupan seseorang yang memiliki nilai-nilai moral tertentu. Sebagaimana pendapat Nurgiyantoro (2005:9) novel adalah karangan prosa yang lebih panjang dari cerita pendek dan menceritakan kehidupan seseorang dengan lebih mendalam dengan menggunakan bahasa sehari-hari serta banyak membahas aspek kehidupan manusia. Mengulas novel terdiri atas tiga indikator pencapaian pembelajaran, yaitu (1) mengidentifikasi unsur intrinsik, (2) merangkum isi novel (berdasarkan urutan alur), dan (3) menilai isi dari segi kelebihan dan kekurangan novel. Oleh karena itu, guru memerlukan strategi untuk membelajarkan KD tersebut agar siswa termotivasi sehingga hasil belajar baik.

Proses belajar mengajar harus melibatkan siswa secara aktif untuk memperoleh pengetahuan dan keterampilan. Paradigma kegiatan belajar mengajar mulai berubah dari 'teacher centered menjadi student centered'. Artinya, siswa tidak hanya menerima informasi dari guru, tetapi lebih aktif dalam mencari pengetahuan sesuai dengan kemampuan yang dimiliki melalui bimbingan dan arahan guru. Guru memerlukan suatu metode pengajaran yang dapat mengarahkan siswa menjadi aktif dalam melakukan kegiatan belajar (Nurhadi, 2002). Menurut Sudrajat (2006) metode pembelajaran adalah cara yang digunakan untuk mengimplementasikan rencana yang sudah disusun dalam bentuk kegiatan nyata dan praktis untuk mencapai tujuan pembelajaran.

Salah satu hal yang perlu diperhatikan oleh guru dalam proses pembelajaran Bahasa Indonesia adalah bagaimana cara penyampaian materi tersebut dapat diterima dan diterapkan oleh peserta didik dengan baik dan menyenangkan. Oleh karena itu, guru diharapkan tidak hanya menuangkan sejumlah informasi kepada siswa, tetapi mengusahakan bagaimana agar konsep-konsep penting dan sangat berguna tertanam kuat dalam diri siswa. Guru merancang penggunaan strategi pembelajaran yang dirasa tepat saat mengajar salah satu KD dalam pembelajaran bahasa Indonesia. Namun, saat pelaksanaan kegiatan belajar mengajar peserta didik kurang termotivasi melakukan instruksi guru sehingga hasil yang diharapkan kurang maksimal.

Berdasarkan hasil tanya jawab antara siswa dan guru saat pembelajaran tentang mengapa bahasa Indonesia yang relatif mudah bagi siswa, tetapi belum menunjukkan hasil evaluasi yang memuaskan. Rata-rata siswa menjawab bahasa Indonesia terlalu banyak bacaan, membutuhkan konsentrasi berpikir dan bernalar serta wawasan kebahasaan dan wawasan kesastraan. Sementara penguasaan siswa terhadap hal tersebut cenderung kurang. Hasil belajar bahasa Indonesia pada KD mengulas novel remaja masih tergolong rendah. Siswa masih kesulitan memahami unsur intrinsik novel remaja, yang meliputi tokoh, perwatakan, tahapan alur, sudut pandang, latar, dan amanat. Kemampuan siswa hanya terbatas pada aspek kognitif, tetapi untuk menganalisis unsur intrinsik menggunakan penalaran masih kurang. Siswa kurang cakap mengeksplorasi, mengenal, dan mengaplikasikan konsep secara langsung dengan kemampuan daya nalar sendiri. Hal ini dapat dilihat dari hasil evaluasi, yaitu $42 \%$ dari 39 siswa (16 siswa) yang mampu mencapai tingkat penguasaan materi memahami unsur intrinsik novel remaja dengan Kriteria Ketuntasan Minimal (KKM) yakni 75. Nilai rata-rata siswa pada pembelajaran ini adalah 68. 
CENDEKIA, Vol. 11, No. 2, Oktober 2017

p ISSN: 1978 2098; e ISSN: 2407 8557

Http://cendekia.pusatbahasa.or.id; Email: cendekiaoslo@gmail.com

Center of Language and Culture Studies, Surakarta, Indonesia

Sulistyaningrum, Indra. 2017. Mengulas Novel Remaja Menggunakan Model

Pembelajaran Think Pair Share pada Siswa SMPN 2 Malang.

Cendekia, (2017), 11(2): 159 170.

Salah satu upaya menciptakan pembelajaran yang menarik untuk meningkatkan motivasi belajar siswa adalah dengan menggunakan model pembelajaran kelompok (Sanjaya, 2013:250). Motivasi adalah dorongan mental yang menggerakkan dan mengarahkan perilaku manusia, termasuk perilaku belajar (Dimyati dan Mudjiono, 2009:80). Salah satu keunggulan model pembelajaran kooperatif adalah mampu untuk meningkatkan prestasi akademik sekaligus kemampuan sosial termasuk mengembangkan rasa harga diri, hubungan interpersonal yang positif dengan yang lain, mengembangkan keterampilan mengelola waktu, dan sikap positif terhadap sekolah. Pembelajaran model kooperatif memberi kesempatan kepada pendidik untuk memaksimalkan peningkatan motivasi belajar siswa.

Salah satu tipe dalam model pembelajaran kooperatif adalah tipe Think Pair Share (TPS). Menurut Huda (2014:136-137) tipe TPS memungkinkan siswa untuk dapat bekerja sama dengan orang lain dan mampu mengoptimalkan partisipasi siswa, mampu memberikan kesempatan sedikitnya delapan kali lebih banyak kepada setiap siswa untuk menunjukkan partisipasi, dan Tipe TPS juga dapat diterapkan untuk semua mata pelajaran dan berbagai tingkatan kelas. Pelaksanaan teknik ini diawali dari berpikir (Think) sendiri tentang pemecahan suatu masalah. Siswa diminta untuk berpasangan (Pair) dan mendiskusikan dengan pasangannya mengenai hasil pemikirannya.

Setelah diskusi selesai pasangan-pasangan yang ada diminta untuk berbagi (Share) dengan pasangan lain tentang apa yang telah diperoleh. Dengan diterapkannya model pembelajaran kooperatif tipe TPS ini diharapkan akan lebih memotivasi siswa untuk belajar karena model pembelajaran yang digunakan lebih menarik dibanding pembelajaran dengan metode ceramah yang diberikan oleh guru. Sebagaimana pendapat Lie (2008:46) bahwa kelebihan metode TPS meliputi (1) meningkatkan partisipasi, (2) cocok untuk tugas sederhana, (3) lebih banyak kesempatan untuk konstribusi masingmasing anggota kelompok, (4) interaksi lebih mudah, dan (5) lebih mudah dan cepat membentuknya. Sementara itu, kekurangan dari TPS yaitu (1) banyak kelompok yang melapor dan perlu dimonitor atau dibutuhkan cukup banyak sumber daya manusia untuk memonitor kelompok belajar dalam TPS, (2) lebih sedikit ide yang muncul, (3) jika ada perselisihan, tidak ada penengah.

Penelitian ini juga didasarkan pada hasil penelitian Rasa (2010) yang menyimpulkan bahwa hasil belajar (nilai rata-rata) mengalami peningkatan dari 60,4 pada masa Prasiklus, 66,9 pada Siklus I dan 71,2 pada Siklus II. Sejalan dengan hasil belajar, tingkat ketuntasan klasikal pun mengalami peningkatan yakni 47,1\% pada Prasiklus, 67,6\% Siklus I, dan 88,2\% Silkus II. Dengan demikian dapat disimpulkan bahwa penerapan pendekatan TPS dalam proses belajar mengajar dapat meningkatkan aktivitas dan hasil belajar.

Penelitian Hariyono (2013) juga menunjukkan bahwa rata-rata persentase keaktifan belajar pada kondisi awal $45 \%$ setelah tindakan siklus I rata- rata persentase keaktifan belajar menjadi $60 \%$, ini menunjukan mengalami peningkatan $15 \%$. Setelah pelaksanaan tindakan siklus II rata-rata persentase keaktifan belajar menjadi $85 \%$ ini berarti meningkat $25 \%$. Secara teoritik dan empirik bahwa melalui pembelajaran 
CENDEKIA, Vol. 11, No. 2, Oktober 2017

p ISSN: 1978 2098; e ISSN: 2407 8557

Http://cendekia.pusatbahasa.or.id; Email: cendekiaoslo@gmail.com

Center of Language and Culture Studies, Surakarta, Indonesia

Sulistyaningrum, Indra. 2017. Mengulas Novel Remaja Menggunakan Model

Pembelajaran Think Pair Share pada Siswa SMPN 2 Malang.

Cendekia, (2017), 11(2): 159 170.

kooperatif dengan model TPS dengan media flash movie dapat meningkatkan keaktifan belajar IPA pada materi perubahan lingkungan fisik dan prosesnya pada siswa kelas IV SD Negeri 5 Karangrejo tahun pelajaran 2012/2013.

Persamaan kedua penelitian tersebut dengan penelitian ini yaitu menggunakan model pembelajaran TPS dan rancangan penelitian tindakan kelas. Sementara itu, perbedaan kedua penelitian tersebut dengan penelitian ini terletak pada materi dan bidang studi.

Berdasarkan uraian tersebut, peneliti memanfaatkan model pembelajaran TPS dalam pembelajaran mengulas novel remaja dengan judul "Peningkatan Kemampuan Mengulas Novel Remaja Menggunakan Model Pembelajaran Think Pair Share Siswa Kelas VIII SMP Negeri 2 Malang.

\section{METODE}

Rancangan penelitian ini ialah penelitian tindakan kelas (classroom action research). Setiap siklus terdiri dari empat tahapan, yaitu: perencanaan tindakan, pelaksanaan tindakan, observasi/evaluasi, dan refleksi (Kemmis dan Mc. Taggart, 1998). Dalam penelitian ini, peneliti merupakan instrumen utama dan pengumpul data. Selain digunakan instrunen penunjang, yaitu lembar pengamatan, pedoman wawancara, rubik penyekoran, catatan lapangan, dan dokumentasi. Kehadiran peneliti mutlak diperlukan dan sangat vital dalam penelitian ini sebab dalam penelitian kualitatif , peneliti merupakan instrumen penelitian. Dalam pelaksanaan penelitian di lapangan peneliti sebagai instrumen utama yang berperan sebagai: (1) perencana tindakan, (2) pengumpul data, (3) Penganalisis data, (4) pelapor hasil penelitian. Peneliti mencatat segala bentuk perubahan yang terjadi. Dalam kegiatan penelitian ini, guru terlibat secara langsung dalam proses perencanaan, tindakan, observasi, dan refleksi (Harsiati, 1999).

Data merupakan bahan yang digunakan peneliti untuk mengkaji hasil pembelajaran. Data dalam penelitian ini meliputi 1) lembar jawaban tahap think, lembar jawaban tahap pair, dan lembar jawaban tahap share, 2) jawaban peserta didik dalam menyelesaikan soal post tes dan ulangan harian, 3) hasil pengamatan proses belajar peserta didik dalam kegiatan diskusi kelompok, presentasi lisan, diskusi kelas, 4) hasil angket respon peserta didik terhadap penggunaan model think pair share, 5) catatan lapangan, 6) dokumentasi. Sumber data yaitu peserta didik kelas VIII B SMP Negeri 2 Malang tahun pelajaran 2012/2013 berjumlah 39 siswa.

Metode pengumpulan data dalam penelitian ini adalah observasi dan catatan lapangan. Perangkat pembelajaran yang digunakan adalah RPP dan lembar kerja siswa. Data hasil observasi yang dilakukan dianalisis dengan memberikan skor untuk penentuan kategori. Analisis data dilakukan dengan metode analisis deskriptif kualitatif, yaitu suatu metode penelitian yang bersifat menggambarkan kenyataan atau fakta sesuai dengan data yang diperoleh saat penelitian. Analisis data dilakukan melalui 3 tahap, yaitu 1) reduksi (penyederhanaan) data, 2) paparan data, dan 3) penyimpulan data.

Indikator keberhasilan dalam penelitian ini yaitu meningkatnya hasil belajar siswa kelas VIII B SMPN 2 Malang tahun pelajaran 2012/2013 pada materi mengulas 
CENDEKIA, Vol. 11, No. 2, Oktober 2017

p ISSN: 1978 2098; e ISSN: 2407 8557

Http://cendekia.pusatbahasa.or.id; Email: cendekiaoslo@gmail.com

Center of Language and Culture Studies, Surakarta, Indonesia

Sulistyaningrum, Indra. 2017. Mengulas Novel Remaja Menggunakan Model

Pembelajaran Think Pair Share pada Siswa SMPN 2 Malang.

Cendekia, (2017), 11(2): 159 170.

novel remaja. Peningkatan tersebut ditandai dengan rata-rata hasil belajar siswa $\geq 80$, dengan ketuntasan belajar $\geq 75 \%$ dari jumlah seluruh siswa.

Data hasil observasi yang dilakukan dianalisis dengan memberikan skor untuk penentuan kategori.

Persentase keberhasilan $=\frac{\sum \text { Deskriptor yang muncul }}{\sum \text { Deskriptor maksimal }} \times 100 \%$

Hasil perhitungan persentase keberhasilan tindakan pada masing-masing tahapan pembelajaran yang diperoleh akan dibandingkan dengan penentuan skor klasifikasi pada tabel berikut ini.

\section{Tabel 1. Penentuan Skor Klasifikasi Observasi}

\begin{tabular}{ll}
\hline Persentase Keberhasilan Tindakan & Taraf Keberhasilan \\
\hline $85 \%-100 \%$ & Sangat Baik \\
\hline $70 \%-85 \%$ & Baik \\
\hline $65 \%-70 \%$ & Cukup \\
\hline $50 \%-65 \%$ & Kurang \\
\hline $0 \%-50 \%$ & Sangat Kurang \\
\hline
\end{tabular}

Data hasil tes siswa dianalisis dengan membandingkan persentase ketuntasan belajar secara klasikal pada penerapan model pembelajaran TPS siklus I dan siklus II. Sementara itu, persentase ketuntasan belajar secara klasikal dihitung dengan cara membandingkan jumlah siswa yang mencapai ketuntasan belajar dengan jumlah siswa secara keseluruhan (siswa maksimal) kemudian dikalikan $100 \%$.

Persentase ketuntasan belajar klasikal $=\frac{\sum \text { Deskriptor yang muncul }}{\sum \text { Deskriptor maksimal }} \quad X 100 \%$

Alur penelitian sebagai berikut.

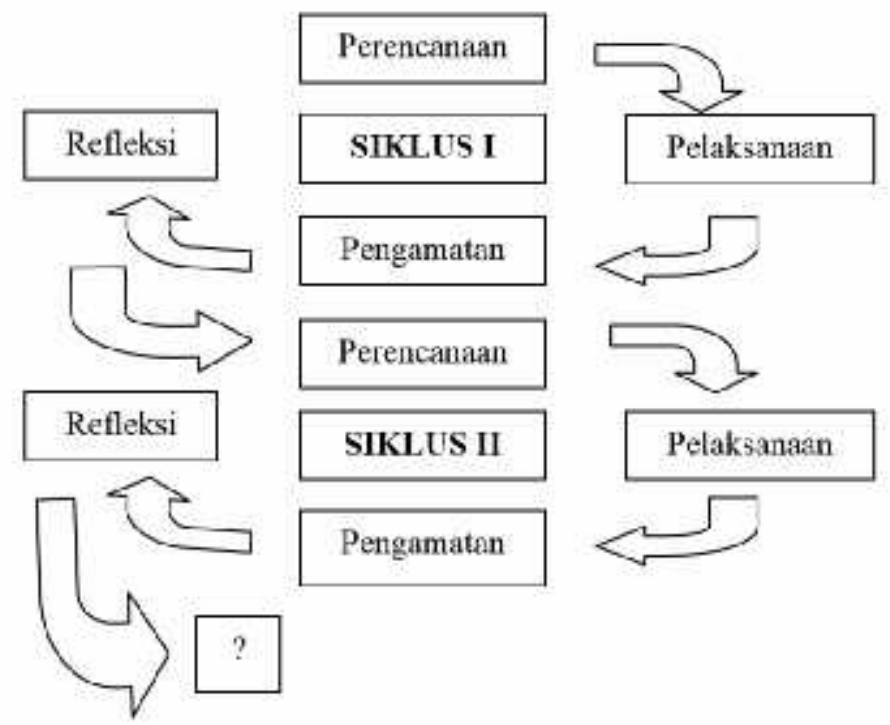


CENDEKIA, Vol. 11, No. 2, Oktober 2017

p ISSN: 1978 2098; e ISSN: 2407 8557

Http://cendekia.pusatbahasa.or.id; Email: cendekiaoslo@gmail.com

Center of Language and Culture Studies, Surakarta, Indonesia

Sulistyaningrum, Indra. 2017. Mengulas Novel Remaja Menggunakan Model

Pembelajaran Think Pair Share pada Siswa SMPN 2 Malang.

Cendekia, (2017), 11(2): 159 170.

Data hasil dokumentasi yang diperoleh berupa foto-foto selama kegiatan pembelajaran berlangsung. Dokumentasi foto ini digunakan sebagai gambaran konkret aktivitas-aktivitas pembelajaran yang terjadi di dalam kelas. Untuk mendapatkan informasi penelitian diperlukan data

\section{HASIL DAN BAHASAN \\ Penerapan TPS pada Siklus I}

Tahap pendahuluan dilaksanakan peneliti dengan menemui kepala sekolah untuk meminta izin melakukan penelitian. Selanjutnya peneliti meminta kesediaan dua orang teman sejawat untuk menjadi pengamat. Peneliti mengadakan pertemuan dengan pengamat untuk membicarakan teknis pelaksanaan, jadwal penelitian, dan Rencana RPP, beserta lembar kegiatan peserta didik. Peneliti juga menyampaikan informasi dan maksud penelitian kepada tim pengembang akademik dan evaluasi SMP Negeri 2 Malang. Selanjutnya peneliti mengadakan pertemuan kembali dengan pengamat untuk menyusun rancangan pembelajaran dan membagi peserta didik dalam kelompok belajar sesuai denah. Pembagian denah disusun berdasarkan pesebaran nilai awal peserta didik. Hal ini dimaksudkan agar mendapatkan kelompok heterogen yang akan saling belajar dan membelajarkan. Fokus yang ditekankan adalah keberhasilan seorang anggota kelompok berpengaruh terhadap keberhasilan kelompoknya dan nilai kelompok akan menjadi nilai individu (Ibrahim, 2002).

Pengambilan data dilaksanakan pada sesuai dengan jadwal pembelajaran yaitu 2 x 40 menit. Pelaksanaan remidi dilaksanakan di luar jam pembelajaran. Peneliti terlebih dahulu memberi arahan tempat duduk peserta didik kelas VIII B terkait pelaksaan kegiatan belajar bahasa Indonesia. Pembagian denah tersebut memperlihatkan tempat duduk peserta didik pada tahap think ( berpikir mandiri), sebanyak 32 peserta didik. Pada tahap pair (berpasangan) sebanyak 16 pasang, dan pada tahap share terdapat 8 kelompok. Siklus I dilaksanakan dengan langkah-langkah pelaksanaan adalah sebagai berikut.

a. Perencanaan

Tahap perencanaan dilaksanakan melalui beberapa langkah, sebagai berikut.

a) Menyusun RPP siklus I, pembagian denah tempat duduk tahap think pair share, format penilaian proses dan hasil belajar untuk materi memahami unsur intrinsik novel remaja terjemahan

b) Menyiapkan Lembar Kegiatan Peserta Didik (LKPD) Siklus I (Lampiran 6 )

c) Menyiapkan format penilaian hasil belajar dan proses belajar .

d) Memberi arahan kepada peserta didik tentang model pembelajaran TPS, meliputi proses dan hasil belajar (cara belajar, mengisi lembar LKPD tahap think, pair, dan share), post tes dan evalusi di akhir siklus, serta pelaksanaan remidi bagi peserta didik yang memperoleh nilai di bawah SKBM.

e) Menyiapkan format pengamatan dan angket untuk peserta didik tentang model pembelajaran.

f) Membagikan lembaran materi penggalan nonel remaja terjemahan berjudul "Matilda" untuk dibaca siswa di rumah. 
CENDEKIA, Vol. 11, No. 2, Oktober 2017

p ISSN: 1978 2098; e ISSN: 2407 8557

Http://cendekia.pusatbahasa.or.id; Email: cendekiaoslo@gmail.com

Center of Language and Culture Studies, Surakarta, Indonesia

Sulistyaningrum, Indra. 2017. Mengulas Novel Remaja Menggunakan Model

Pembelajaran Think Pair Share pada Siswa SMPN 2 Malang.

Cendekia, (2017), 11(2): 159 170.

\section{b. Pelaksanaan}

Tahap pelaksanaan dilakukan melalui beberapa langkah, sebagai berikut.

a) Peneliti (untuk selanjutnya disebut sebagai guru) membuka pelajaran dengan apersepsi dan motivasi serta mengingatkan kembali secara umum tentang pembelajaran dengan model kooperatif think pair share kepada seluruh peserta didik.

b) Guru meminta peserta didik untuk duduk sesuai denah yang sudah diberikan sebelumnya.

c) Peserta didik duduk berdasarkan denah, guru membagikan LKPD dan lembar jawaban Think

d) Peseta didik secara mandiri mengerjakan LKPD dengan waktu yang telah ditentukan guru, yakni 10 menit

e) Guru meminta peserta didik mengerjakan LKPD secara berpasangan dengan teman sebangku dan menuliskan jawaban pada LKPD tahap pair.

f) Peserta didik berpasangan mengerjakan LKPD tahap pair sesuai dengan waktu yang telah ditentukan yakni 15 menit.

g) Guru meminta tiap pasang siswa untuk saling menjelaskan hasil jawaban dengan pasangan yang lain sesui dengan denah dan menuliskan kembali pada lembar jawaban share. memberi batasan waktu 15 menit.

h) Pengamat berkeliling untuk mengamati kegiatan yang dilakukan setiap kelompok dan menuliskan temuan-temuannya dalam lembar pengamat yang sudah disediakan.

i) Setelah batas waktu yang ditentukan berakhir, mempersilahkan wakil setiap kelompok mempresentasikan hasil kerja pada LKS nya secara bergiliran. Kelompok lain dapat menyanggah ataupun menambahkan jawaban dari kelompok yang presentasi.

j) Membimbing peserta didik menyimpulkan hasil diskusi kelas.

k) Mengumpulkan seluruh hasil LKPD yang sudah dikerjakan peserta didik.

1) Membagikan soal post tes

m) Guru dengan pengamat mencatat semua temuan selama proses belajar berlangsung.

c. Observasi dan Evaluasi

Selama proses belajar berlangsung, bersama pengamat mencatat semua temuan yang ada pada lembar observasi yang sudah dibuat. Aspek-aspek yang diamati meliputi kegiatan diskusi kelompok, dan diskusi kelas. Selain pengamatan secara langsung juga dilakukan penilaian melalui LKPD tahap think, pair, dan share, post tes, dan ulangan harian.

Berdasarkan hasil observasi, catatan lapangan, dan hasil evaluasi pada siklus I diperoleh gambaran data hasil nilai akhir peserta didik sejumlah 39 siswa. Perhatikan sebaran hasil dalam tabel 1 berikut. 
CENDEKIA, Vol. 11, No. 2, Oktober 2017

p ISSN: 1978 2098; e ISSN: 2407 8557

Http://cendekia.pusatbahasa.or.id; Email: cendekiaoslo@gmail.com

Center of Language and Culture Studies, Surakarta, Indonesia

Sulistyaningrum, Indra. 2017. Mengulas Novel Remaja Menggunakan Model

Pembelajaran Think Pair Share pada Siswa SMPN 2 Malang.

Cendekia, (2017), 11(2): 159 170.

Tabel 1 Hasil Tes Siklus 1

\begin{tabular}{lllccc}
\hline No. & Rentang Nilai & \multicolumn{1}{c}{ Kategori } & Frekuensi & $\begin{array}{c}\text { Persentase } \\
\%\end{array}$ & $\begin{array}{c}\text { Rata-rata } \\
\text { Kelas }\end{array}$ \\
\hline 1. & $91-100$ & Sangat baik & 1 & 2.56 & \\
\hline 2. & $81-90$ & Baik & 3 & 7.69 & \\
\hline 3. & $75-79$ & Cukup & 14 & 35.90 & \\
\hline 4. & $40-74$ & Kurang & 21 & 53.85 & 74.73 \\
\hline 5. & $25-39$ & Sangat kurang & 0 & 0 & \\
\hline 6. & $10-24$ & Gagal & 0 & 0 & \\
\hline & & Jumlah & 39 & $100 \%$ & \\
\hline
\end{tabular}

Berdasarkan tabel tersebut, model pembelajaran TPS dapat meningkatkan hasil belajar siswa dalam mengulas novel remaja. Hal ini ditunjukkan pada hasil persentase kelas mencapai 74,73 dengan rincian perolehan yaitu kategori sangat baik dengan rentang nilai 91-100 ada 1 siswa (2,56\%), kategori baik dengan rentang nilai 81-90 ada 3 siswa (7,69\%), kategori cukup dengan rentang nilai 75-79 ada 14 siswa $(35,90 \%)$, sedangkan kategori kurang ada 14 siswa $(53,85 \%)$. Aktivitas siswa belum menunjukkan kriteria keberhasilan karena hasil persentase keaktifan siswa masih $\leq 80 \%$. Berdasarkan tabel tersebut, diketahui bahwa proses belajar yang terdiri dari diskusi kelompok dan diskusi kelas perlu ditingkatkan. Demikian halnya yang tampak pada lembar kegiatan siswa tahap think (berpikir mandiri) masih cukup banyak siswa yang mendapatkan nilai sangat rendah.

Berdasarkan hasil observasi dan hasil evaluasi, ada beberapa catatan penting selama siklus I sebagai berikut:

a. Perlu ketegasan pengaturan waktu sesuai dengan masing-masing tahapan karena peserta didik cenderung menyelesaikan tugas hingga selesai terutama pada tahap think tanpa memperhatikan batasan waktu.

b. Tidak semua pasangan dapat bekerjasama dengan baik. Beberapa peserta didik terlihat pasif dan cenderung menyerahkan hasil jawaban tahap pair pada pasangannya yang memuiliki kemampuan awal lebih tinggi.

c. Diskusi kelas kurang berjalan dengan baik karena peserta didik yang lain masih sibuk menyelesaikan tugas kelompoknya masing-masing.

d. Pada tahap think, masih perlu diperhatikan apakah siswa menemukan kesulitan menganalisis soal atau kurang paham dengan instruksi guru.

e. Kegiatan tahap pair dan tahap share menunjukkan hasil yang cukup baik. Terbukti dari hasil belajar yang mengalami peningkatan dibandingkan dengan tahapan sebelumnya, yakni tahap think.

\section{Penerapan TPS pada Siklus II}

Penerapan model pembelajaran TPS pada siklus II dilaksanakan seperti pada siklus I. Perbedaan terletak pada novel remaja yang diulas. Perolehan hasil belajar siswa dalam mengulas novel remaja menggunakan model pembelajaran TPS dijabarkan pada tabel berikut. 
CENDEKIA, Vol. 11, No. 2, Oktober 2017

p ISSN: 1978 2098; e ISSN: 2407 8557

Http://cendekia.pusatbahasa.or.id; Email: cendekiaoslo@gmail.com

Center of Language and Culture Studies, Surakarta, Indonesia

Sulistyaningrum, Indra. 2017. Mengulas Novel Remaja Menggunakan Model

Pembelajaran Think Pair Share pada Siswa SMPN 2 Malang.

Cendekia, (2017), 11(2): 159 170.

Tabel 2 Perolehan Hasil Belajar Siklus II

\begin{tabular}{lllccc}
\hline No. & Rentang Nilai & \multicolumn{1}{c}{ Kategori } & Frekuensi & $\begin{array}{c}\text { Persentase } \\
\%\end{array}$ & $\begin{array}{c}\text { Rata-rata } \\
\text { Kelas }\end{array}$ \\
\hline 1. & $91-100$ & Sangat baik & 5 & 12.82 & \\
\hline 2. & $81-90$ & Baik & 18 & 46.15 & \\
\hline 3. & $75-79$ & Cukup & 14 & 35.90 & \\
\hline 4. & $40-74$ & Kurang & 2 & 5.13 & 84.53 \\
\hline 5. & $25-39$ & Sangat kurang & 0 & 0 & \\
\hline 6. & $10-24$ & Gagal & 0 & 0 & \\
\hline & & Jumlah & 39 & $100 \%$ & \\
\hline
\end{tabular}

Berdasarkan tabel tersebut, model pembelajaran TPS dapat meningkatkan hasil belajar siswa dalam mengulas novel remaja. Hal ini ditunjukkan pada hasil persentase kelas mencapai 84,53 dengan rincian perolehan yaitu kategori sangat baik dengan rentang nilai $91-100$ ada 5 siswa (12,82\%), kategori baik dengan rentang nilai $81-90$ ada 18 siswa (46,15\%), kategori cukup dengan rentang nilai 75-79 ada 7 siswa $(35,90 \%)$, sedangkan kategori kurang ada 2 siswa (5,13\%). Aktivitas siswa telah menunjukkan kriteria keberhasilan karena hasil persentase keaktifan siswa $\geq 80 \%$. Kunandar (2010:277) menjelaskan bahwa aktivitas belajar adalah keterlibatan siswa dalam bersikap, pikiran, perbuatan dan aktivitas dalam kegiatan pembelajaran guna menunjang keberhasilan proses pembelajaran dan memperoleh manfaat.

Aktivitas yang diharapkan muncul dalam kegiatan pembelajaran yaitu: (a) aktif mengajukan pertanyaan, (b) merespon aktif pertanyaan-pertanyaan lisan dari guru dan teman, (c) berpartisipasi aktif dalam kelompok untuk memecahkan masalah pembelajaran yang dilaksanakan, (d) melaksanakan instruksi/perintah, dan (e) semangat/antusias dalam mengikuti kegiatan pembelajaran memberikan pendapat saat diskusi.

Selama proses belajar berlangsung, pengamat dan peneliti mencatat semua temuan yang ada pada lembar observasi yang sudah dibuat. Aspek-aspek yang diamati meliputi kegiatan diskusi kelompok dan diskusi kelas. Selain pengamatan secara langsung juga dilakukan penilaian melalui LKPD tahap think, pair, dan share, post tes, dan ulangan harian.

Berdasarkan hasil observasi dan evalusi, diperoleh gambaran bahwa proses belajar telah berjalan dengan lebih baik dapat dilihat dari nilai akhir proses dan hasil belajar. Hanya ada dua siswa yang belum tuntas belajar dan perlu diberikan remidi. Pada siklus II, sebanyak 98\% siswa mengalami peningkatan hasil belajar dibandingkan dengan siklus I. Skor terendah adalah 70 (satu siswa) skor tertinggi adalah 96 (satu siswa). Berdasarkan hasil siklus I dan siklus II dapat dilihat pada grafik berikut. 


\section{Grafik 1 Peningkatan Hasil Belajar Siswa}

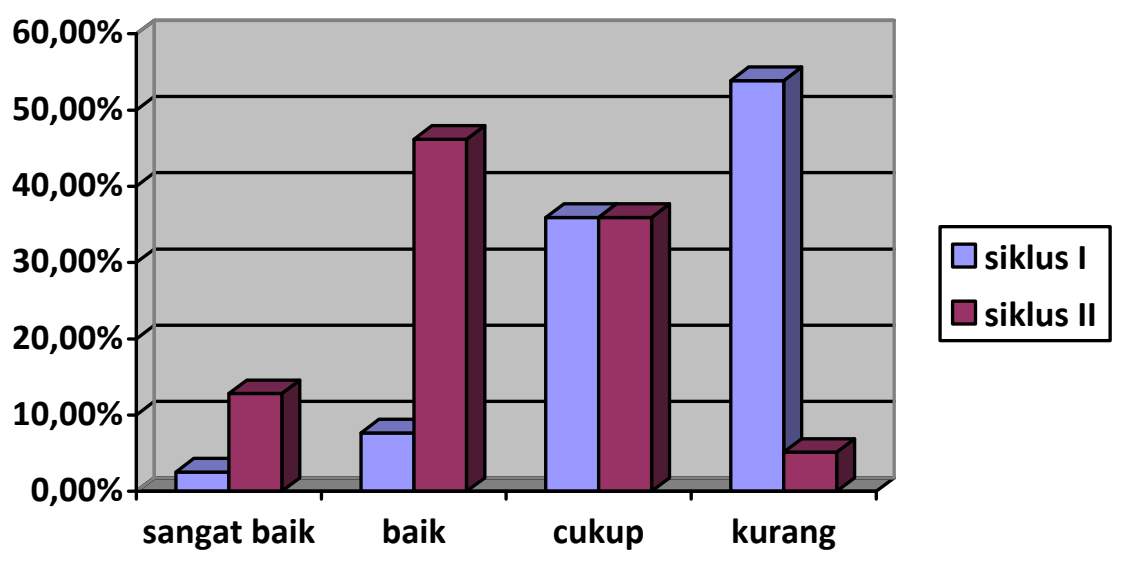

Berdasarkan grafik tersebut dapat diketahui peningkatan hasil belajar siswa dalam mengulas novel remaja menggunakan model pembelajaran think pair share. Pada siklus I siswa yang memperoleh nilai sangat baik $\leq 5 \%$, siklus II meningkat menjadi $\geq$ $10 \%$. Perolehan nilai kategori baik pada siklus I $\leq 10 \%$, sedangkan pada siklus II mencapai $\geq 40 \%$. Perolehan nilai kategori cukup pada siklus I dan siklus II sama yaitu $\geq$ $30 \%$. Pada siklus I, perolehan nilai kurang masih tinggi $250 \%$ sedangkan pada siklus II menurun secara signifikan $\leq 5 \%$.

\section{SIMPULAN}

Berdasarkan hasil penelitian dan pembahasan disimpulkan bahwa implementasi model pembelajaran TPS dapat meningkatkan hasil belajar mengulas novel remaja siswa kelas VIII SMP Negeri 2 Malang tahun ajaran 2012/2013 yang dibuktikan dengan adanya peningkatan persentase skor motivasi belajar dan hasil belajar pada tiap siklusnya. Hasil tersebut diperoleh melalui observasi. Berdasarkan hasil siklus I, model pembelajaran TPS dapat meningkatkan hasil belajar siswa dalam mengulas novel remaja. Hal ini ditunjukkan pada hasil persentase kelas mencapai 84,53 dengan rincian perolehan yaitu kategori sangat baik dengan rentang nilai $91-100$ ada 5 siswa $(12,82 \%)$, kategori baik dengan rentang nilai 81-90 ada 18 siswa (46,15\%), kategori cukup dengan rentang nilai $75-79$ ada 7 siswa $(35,90 \%)$, sedangkan kategori kurang ada 2 siswa $(5,13 \%)$. Aktivitas siswa telah menunjukkan kriteria keberhasilan karena hasil persentase keaktifan siswa $\leq 80 \%$. Pada siklus II, model pembelajaran TPS dapat meningkatkan hasil belajar siswa dalam mengulas novel remaja. Hal ini ditunjukkan pada hasil persentase kelas mencapai 84,53 dengan rincian perolehan yaitu kategori sangat baik dengan rentang nilai $91-100$ ada 5 siswa (12,82\%), kategori baik dengan rentang nilai $81-90$ ada 18 siswa $(46,15 \%)$, kategori cukup dengan rentang nilai 75-79 ada 7 siswa $(35,90 \%)$, sedangkan kategori kurang ada 2 siswa $(5,13 \%)$. Aktivitas siswa telah menunjukkan kriteria keberhasilan karena hasil persentase keaktifan siswa $280 \%$. 
CENDEKIA, Vol. 11, No. 2, Oktober 2017

p ISSN: 1978 2098; e ISSN: 2407 8557

Http://cendekia.pusatbahasa.or.id; Email: cendekiaoslo@gmail.com

Center of Language and Culture Studies, Surakarta, Indonesia

Sulistyaningrum, Indra. 2017. Mengulas Novel Remaja Menggunakan Model

Pembelajaran Think Pair Share pada Siswa SMPN 2 Malang.

Cendekia, (2017), 11(2): 159 170.

Dari data observasi dan angket yang diperoleh dapat disimpulkan bahwa dengan dilakukannya implementasi model pembelajaran TPS dapat meningkatkan hasil belajar mengulas novel remaja siswa kelas VIII SMP Negeri 2 Malang tahun ajaran 2012/2013.

\section{SARAN}

Berdasarkan hasil penelitian, ada beberapa saran sebagai berikut.

a. Bagi tenaga pengajar yang tertarik untuk menerapkan model pembelajaran kooperatif think pair share dalam kegiatan belajar mengajar di kelas, sebaiknya mempertimbangkan ketepatan waktu dalam tiap tahapan, ketepatan pemilihan KD, persiapan guru sebelum KBM, dan kesiapan peserta didik.

b. Bagi peneliti lain yang berminat mengaplikasikan modelpembelajaran kooperatif think pair share, hasil penelitian tindakan kelas ini dapat digunakan sebagai bahan perbandingan dan dapat dikembangkan lebih lanjut sehingga dikemudian hari proses dan hasil pembelajaran bahasa Indonesia menjadi lebih baik.

\section{DAFTAR RUJUKAN}

Arikunto, Suharsimi. 2001. Dasar-Dasar Evaluasi Pendidikan. Jakarta: Bumi Aksara.

Arikunto, Suharsimi. 2006. Prosedur Penelitian, Suatu Pendekatan Praktik. Jakarta: Rineka Cipta.

Atmazaki. 2013. Implementasi Kurikulum 2013 Mata Pelajaran Bahasa Indonesia: Pola Pikir, Pendekatan Ilmiah, Teks (Genre), dan Penilaian Otentik. (Online). http://ejournal.unp.ac.id/index.php/isla/article/download/3962/3193

Dasna, I Wayan dan Fatchan, A. 2008. Penelitian Tindakan Kelas dan Penulisan Karya Ilmiah. Naskah untuk Pendidikan dan Latihan Profesi Guru (PLPG). Malang:

Panitia Sertifikasi Guru Rayon 15 Universitas Negeri Malang.

Dimyati dan Mudjiono. 2009. Belajar dan Pembelajaran. Jakarta: Rineka Cipta.

Hariyono. 2013. Penerapan Pembelajaran Kooperatif Model Think Pair Share untuk Meningkatkan Aktivitas Belajar IPA Melalui Media Flash Movie Siswa Kelas IV SD Negeri 5 Karangrejo Tahun Pelajaran 2012/2013. (Online). http/www.eprints.ums.ac.id diakses 10 Juli 2015.

Harsiati. 1999. Penelitian Tindakan Kelas dalam Pengajaran Bahasa. Malang: IKIP Malang.

Huda, Miftahul. 2014. Cooperative Learning. Yogyakarta: Pustaka Pelajar.

Lie, Anita. 2008. Cooperative Learning: Mempraktikkan Cooperative Learning di Ruang-Ruang Kelas. Jakarta: Gramedia.

Nurgiantoro, Burhan. 2013. Penilaian Pembelajaran Bahasa. Yoyakarta: BPFE.

Nurhadi, 2002 Pendekatan Kontekstual (Contextual Teaching and Learning). Malang: Universitas Negeri Malang.

Nur'aini. 2010. Peningkatan Aktivitas Belajar dalam Pemahaman Cerita Pendek dengan Menggunakan Model Kooperatif Two Stay Two Stray (TSTS) Siswa Kelas IX_A SMP Negeri 5 Malang Semester Ganjil Tahun 2010 -2011. Penelitian Tindakan Kelas. 
CENDEKIA, Vol. 11, No. 2, Oktober 2017

p ISSN: 1978 2098; e ISSN: 2407 8557

Http://cendekia.pusatbahasa.or.id; Email: cendekiaoslo@gmail.com

Center of Language and Culture Studies, Surakarta, Indonesia

Sulistyaningrum, Indra. 2017. Mengulas Novel Remaja Menggunakan Model

Pembelajaran Think Pair Share pada Siswa SMPN 2 Malang.

Cendekia, (2017), 11(2): 159 170.

Rasa, Sucipto. 2010. Penggunaan Model Pembelajaran Kooperatif Tipe TPS (Think-

Pair-Share) Untuk Meningkatkan Kemampuan Memahami Materi Pelajaran

Sejarah Pada Siswa Kelas VIII E SMP N 3 Ungaran Tahun Ajaran 2009/2010.

(Online). http//www.lib.unnes.ac.id diakses 10 Juli 2015.

Sanjaya, Wina. 2013. Kurikulum dan Pembelajaran: Teori dan Praktek

Pengembangan Kurikulum Tingkat Satuan Pendidikan (KTSP). Jakarta:

Kencana. 